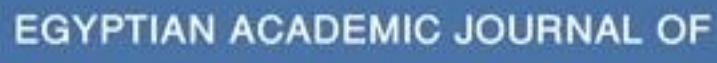 BiOLOGGCA. SCEENCES ENTOMOLOGY
}

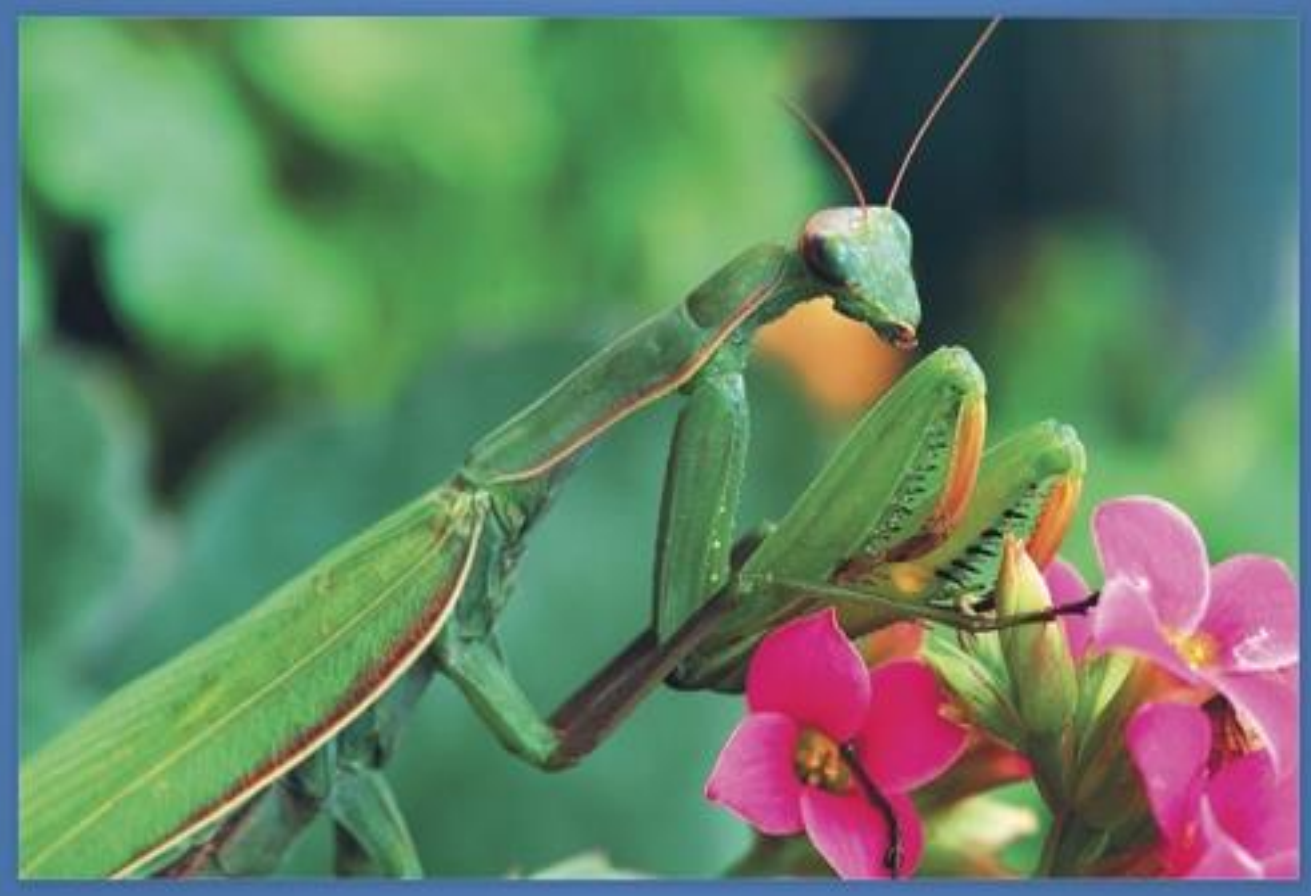

ISSN

1687-8809

WWW.EAJBS.EG.NET

Vol. 13 No. 4 (2020) 

Egypt. Acad. J. Biolog. Sci., 13(4):199-211(2020)

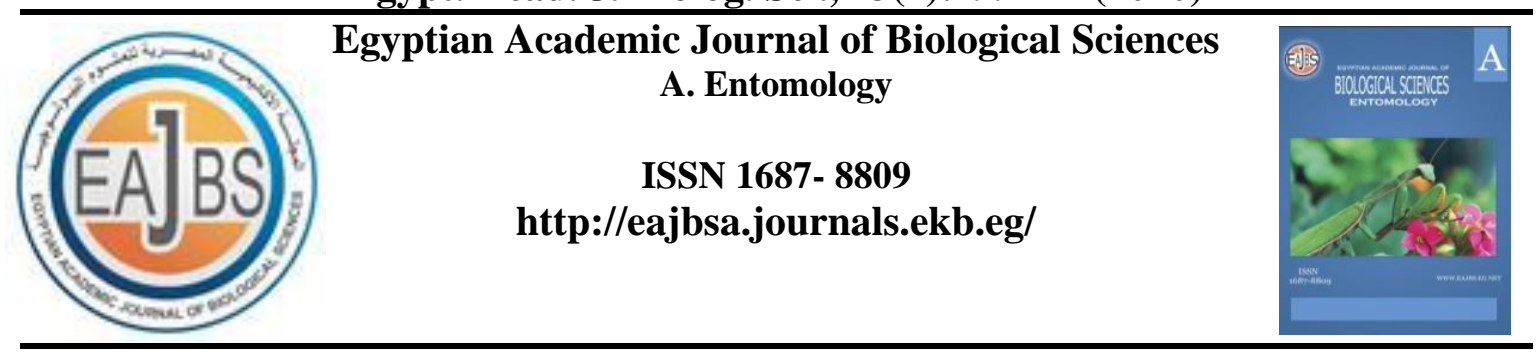

\section{Toxicity and Deleterious Impacts of the Deathstalker Scorpion, Leiurus quinquestriatus, Venom on Development of the Greater Wax Moth, Galleria mellonella (Lepidoptera: Pyralidae)}

Ghoneim, K.*; Hamadah, Kh.; Tanani, M. and Emam, D.

Department of Zoology and Entomology, Faculty of Science, Al-Azhar University, Cairo, Egypt

"Corresponding author: E.mail: karemghoneim@gmail.com

\section{ARTICLE INFO}

Article History

Received:7/9/2020

Accepted:28/11/2020

Keywords:

Adult, desiccation,

larva,

metamorphosis,

morphogenesis,

mortality, pupation,

survival.

\section{ABSTRACT}

The greater wax moth, Galleria mellonella L. (Lepidoptera: Pyralidae) is the most destructive pest of the honey bee, Apis mellifera, throughout the world. The current study was carried out to evaluate the toxicity and disruptive effects of the venom of deathstalker scorpion, Leiurus quinquestriatus (Buthidae: Scorpiones) on the growth, development, and metamorphosis of this pest. The newly moulted $3^{\text {rd }}$ instar larvae were fed on an artificial diet treated with a series of venom concentrations $(250,500,1000,2000,4000$, and $8000 \mathrm{ppm})$. The present results could be summarized as follows. The venom exhibited considerable toxicity against larvae. Also, the pupae suffered a lethal action of the venom, in a dose-dependent course. In contrast, adult survival was not affected by the tested venom. The $\mathrm{LC}_{50}$ was calculated in $3428.9 \mathrm{ppm}$. With regard to growth and development, the somatic weight gain of larvae was slightly reduced proportionally to the concentration. The larval growth rate increasingly regressed by the ascending concentration. The larval duration was remarkably shortened, in a dose-dependent manner. The pupation rate of treated larvae was significantly regressed, in a dose-dependent course. Also, the pupal duration was shortened. Pupae lost more body water than control pupae. The venom failed to affect the metamorphosis program.

\section{INTRODUCTION}

The greater wax moth, or honeycomb moth, Galleria mellonella L. (Lepidoptera: Pyralidae) is widely distributed throughout the world. Its presumed native range includes Europe and adjacent Eurasia, and was introduced into other continents, including North America and Australia (Savela, 2009). Although the adults do not feed, because they have atrophied mouth parts, the voracious nature of larval feeding and tunneling lead to the destruction of the honeycomb, and subsequent to the death of weak colonies (Awasthi and Sharma, 2013; Kwadha et al., 2017), especially in temperate, tropical and subtropical beekeeping regions, since the warm temperature enhances a rapid development of this moth (Chandel et al., 2003; Ellis et al., 2013; Mohamed et al., 2014).

For the control of G. mellonella, various physical methods have been adopted, 
including freezing, heating (high temperature), $\mathrm{CO}_{2}$, and sulphur fumigation against larvae and pupae (Ahmed et al., 1993; Calderone, 2000; Owayss and Abd-Elgayed, 2007). Akyol et al. (2009) determined the effectiveness of $\mathrm{CO}_{2}$ against the eggs, larvae and pupal period of G. mellonella in stored honeycombs. For more information, see Ramos-Rodríguez et al. (2007) and Christen et al. (2008). Ozone gas was assessed as a control measure for G. mellonella and honey bee Apis mellifera pathogens (James, 2011). Synthetic insecticides of different categories had been used for controlling G. mellonella (Durmuş and Büyükgüzel, 2008; Sak and Uckan, 2009). Several biological control agents, such as the natural enemies of predators and parasitoids, along with entomopathogenic nematodes, viruses and fungi, had been assessed on G. mellonella (Dindo et al., 2001; Armendariz et al., 2002; Hussaini, 2003; Ellis et al., 2013; George et al., 2019). Also, many studies had been conducted on the sterile insect technique (or inherited sterility) for controlling G. mellonella (Khalil et al., 1993; Ebadi et al., 2001; Carpenter et al., 2005; El-Kholy and Mikhaiel, 2008). In addition, insect hormone analogues, insect growth regulators had been assessed against G. mellonella (Willems et al., 2002; Izzetoglu and Karacali, 2003; Unsal et al., 2004; Awasthi and Sharma, 2012; Pamita and Priyanka, 2013). Natural compounds from the plant origins could be efficient alternatives to conventional fumigants against G. mellonella (Rajendran and Sriranjini, 2008; Abbasipour et al., 2009; Mahmoudvand et al., 2011; Basedow et al., 2012; Elbehery et al., 2016; Er et al., 2017).

In the last two decades, an important interest of investigation by agrochemical companies in the development of highly selective biopesticides derived from animals. Also, natural products of animal origin have been described as very good alternative agents for controlling G. mellonella. One source of these selective animal-derived biopesticides leads is venom-derived peptides from different sources including the venomous predatory/parasitoid arthropods, such as spiders (Harrison and Bonning, 2000; Tedford et al., 2004; Nicholson, 2006), scorpions (Froy et al., 2000; Taniai et al., 2002), wasps (Dahlman et al., 2003), cone snails (Olivera, 2002) and some marine animals (Whetstone and Hammock, 2007; Windley et al., 2012; Nakasu et al., 2014), as well as arthropod hormones and neuropeptides (Altstein et al., 2000; Altstein, 2004).

Scorpion is a mysterious creature in the animal world. It has poisonous venom (Possani et al., 2000) and can be fluorescent (Frost et al., 2001) that unique features increasingly attracted scientists' attention and interests throughout the world (Cao et al., 2013; Ma and Shi, 2014). The deathstalker scorpion or yellow scorpion Leiurus quinquestriatus Hemprich \& Ehrenberg (Buthidae: Scorpiones: Arachnida) can be found in desert and scrubland habitats ranging from North Africa through to the Middle East. In Egypt, Saleh et al. (2017) reported that two species of scorpions (Androctonus amoreuxi and L. quinquestriatus) have been recorded from six eco-geographical regions. The toxicity of venom solutions from some scorpion species was assessed against the mealworm Tenebrio molitor. The most potent toxicity was exhibited by the venom of $L$. quinquestriatus (Valk and Meijden, 2014).

As reported by some authors (Gurevitz, 2010; Leng et al., 2011), the scorpion toxins contain toxins active against insects and are valuable as leads for the development and synthesis of eco-friendly insecticides, since they exhibited no effect on beneficial insects or mammals (Fabiano et al., 2008; Gurevitz, 2010). However, Joseph and George (2012) reviewed the insecticidal activities of scorpion toxins on a broad range of insect pests and concluded that the scorpion toxins provide safe biopesticides. The objective of the current study was to evaluate the toxicity and disruptive effects of L. quinquestriatus venom on the growth, development, and metamorphosis of G. mellonella. 


\section{MATERIALS AND METHODS}

\section{Experimental Insect:}

A culture of the greater wax moth Galleria mellonella (Lepidoptera: Pyralidae) was maintained in the laboratory of Entomology, Faculty of Science, Al-Azhar University, Cairo, Egypt under controlled conditions $\left(27 \pm 2^{\circ} \mathrm{C}, 65 \pm 5 \%\right.$ R.H., photoperiod $14 \mathrm{~h} \mathrm{~L}$, and $10 \mathrm{~h} \mathrm{D}$ ). This culture was originated from a sample of larvae kindly obtained from a culture of susceptible strain maintained for several generations in Plant Protection Unit, Desert Research Center, Cairo, Egypt. Larvae were transferred into glass containers, tightly covered with muslin cloth secured with rubber bands. After reviewing different techniques of the artificial diet described by some authors (Metwally et al., 2012; Nitin et al., 2012), G. mellonella larvae in the present culture had been provided with an artificial diet as described by Bhatnagar and Bareth (2004). It contained maize flour (400 g), wheat flour, wheat bran, and milk powder, $200 \mathrm{~g}$ of each. Also, the diet was provided with glycerol $(400 \mathrm{~g})$, bee honey $(400 \mathrm{~g})$, yeast $(100 \mathrm{~g})$. The resulting pupae were then collected and transferred into clean jars provided with a layer of moistened sawdust on the bottom. The emerged adult moths were kept in glass containers provided with white paper scraps, as oviposition sites. After mating, female moths were allowed to lay eggs. The egg patches were collected daily and transferred into Petri dishes containing a layer of an artificial diet for feeding of the hatching larvae.

Scorpion Collection, Identification, and Obtaining of Venom:

Sixty-five adult individuals of the deathstalker scorpion, Leiurus quinquestriatus (Buthidae: Scorpiones), were collected from Garf Hessin at 23.289024N32.776828E, west of Nasser Lake, Aswan, Egypt. Scorpions were collected in the daytime by random searching their hiding places, mostly under rocks and other favorable shelters (Williams, 1968). The collected specimens were kept individually in plastic containers at $25-28^{\circ} \mathrm{C}$. The specimens were examined with a stereoscopic binocular microscope and taxonomically identified to the species using the morphological description keys (Vachon, 1966; El-Hennawy, 1987; Badry et al., 2018).

Venom was obtained by electric stimulation (20 Volt) in the articulation of the telson according to Sarhan et al. (2012). Milking of scorpion had been carried out as venom drops collected into an Eppendorf tube. Then, the collected drops were centrifuged at 14000 r.p.m for 15 minutes at $4^{\circ} \mathrm{C}$. The supernatant was pooled, freezedried, and stored at $20^{\circ} \mathrm{C}$. The lyophilized samples were dissolved in distilled water and centrifuged at 15000 r.p.m for 15 minutes at $4^{\circ} \mathrm{C}$.

\section{Preparation of Concentrations and Larval Treatment:}

A series of concentration levels of the scorpion L. quinquestriatus venom was prepared by diluting with distilled water in volumetric flasks as follows: 8000, 4000, 2000, 1000, $500 \& 250$ ppm.

Bioassay tests were carried out using the newly moulted $3^{\text {rd }}$ instar larvae. Ten grams of the diet were mixed with $2 \mathrm{ml}$ of each concentration of the animal product before introduction to larvae, as a food. Control larvae were provided with a water-treated diet. Ten replicates of treated and control larvae (one larva/replicate) were kept separately in glass vials under the aforementioned laboratory conditions. The larvae were allowed to feed on this treated diet along the larval stage. All biological criteria were recorded daily after the first $24 \mathrm{hrs}$ feeding.

\section{Criteria of Study:}

\section{Toxicity Test:}

All mortalities of treated and control (larvae, pupae, and adults) were recorded every day and corrected according to Abbott's formula (Abbott, 1925) as follows: 
$\%$ corrected mortality $=\frac{\% \text { test mortality }-\% \text { control mortality }}{100-\% \text { control mortality }} \times 100$

The LC50 values were calculated for general mortality according to Finny (1971).

2. Growth, Development and Metamorphosis:

Weight gain: Each individual larva (treated and control) was carefully weighed every day using a digital balance for calculating the body weight gain as follows:

Initial weight (before the beginning of the experiment) - final weight (at the end of the experiment).

Growth rate: Growth rate (GR) can be calculated according to (Waldbauer, 1968) as follows:

$\mathrm{GR}=$ fresh weight gain during feeding period/feeding period $\mathrm{X}$ mean fresh bodyweight of larvae during the feeding period.

Pupation rate: The pupation rate was expressed in $\%$ of the successfully developed pupae.

Pupal water loss: Pupal water loss was calculated depending on the date of the initial and final weights of the pupae, as follows:

\section{Statistical Data Analysis:}

Water loss $\%=[$ initial weight - final weight /initial Weight $] \times 100$

Data obtained were analyzed by the Student's $t$-distribution, and refined by Bessel correction (Moroney, 1956) for the test significance of the difference between means.

\section{RESULTS}

\section{Toxicity and Lethal Effects of $L$. quinquestriatus venom:}

The newly moulted $3^{\text {rd }}$ instar larvae of $G$. mellonella were treated with six concentration levels of scorpion venom $(250,500,1000,2000,4000$, and $8000 \mathrm{ppm})$, via the artificial diet. Data of toxicity and lethal effects were assorted in Table (1). Depending on these data, scorpion venom exhibited toxicity against larvae, except at the lowest concentration level. At the higher three concentration levels, scorpion venom treatment caused $40 \%$ larval mortality and then decreased with the decreasing concentration. No mortality was observed among control larvae. The successfully developed pupae suffered a lethal action of scorpion venom, in a dose-dependent course, except at the two lower concentration levels, since no mortality was observed (33.33, 16.67, 16.67 and $12.50 \%$ mortality, at $8000,4000,2000$ and $1000 \mathrm{ppm}$, respectively, compared to $00 \%$ mortality of control pupae). With regard to the successfully emerged adults, scorpion venom failed to affect their survival. The corrected mortality was found in a dose-dependent manner $(20,30,50,50$ and 60\%, at 500, 1000, 2000, 4000 and 8000 ppm, respectively). The $\mathrm{LC}_{50}$ value was calculated in $3428.9 \mathrm{ppm}$ (Table 1).

\section{Effects of $L$. quinquestriatus Venom on Growth and Development:}

The most important criteria of growth, development, and metamorphosis of $G$. mellonella, after treatment of $3^{\text {rd }}$ instar larvae with six concentration levels of scorpion venom, were summarized in Table (2). Depending on these data, the somatic weight gain of larvae was slightly reduced proportionally to the concentration level. A similar result was recorded for the growth rate. In contrast, the larval duration was considerably shortened, in a dose-dependent manner $(29.00 \pm 1.3,27.00 \pm 2.0,27.00 \pm 2.7,27.00 \pm 1.4$, $26.00 \pm 1.3$ and $24.67 \pm 1.6$ days, at 250, 500, 1000, 2000, 4000 and $8000 \mathrm{ppm}$, respectively, compared to $30.86 \pm 1.6$ days of control larvae). In addition, the developmental rate of treated larvae was higher than that of control larvae. Depending on the data arranged in the same table, the pupation rate of treated larvae was not affected at 
the lowest concentration level of scorpion venom but it regressed parallel to other concentration levels. In other words, scorpion venom hindered the pupation process in a dose-dependent course. Also, the pupal duration was slightly shortened, depending on the venom concentration $(8.88 \pm 2.0,8.78 \pm 2.1,8.31 \pm 2.0,7.99 \pm 2.2$ and $7.92 \pm 2.1$ days of treated pupae, at 500,1000, 2000, 4000, and 8000 ppm, respectively, vs. $9.00 \pm 1.2$ days of control pupae).

Because the pupal death may be due to the desiccation caused by the scorpion venom, loss of body water was estimated in $\%$. The successfully developed pupae lost more body water than the control pupae but in a reverse correlation with the venom concentration (see Table 2). However, the tested scorpion venom failed to affect the metamorphosis program, since no larval-pupal or malformed pupae had been produced.

Table 1: Lethal effects (\%) of scorpion L. quinquestriatus venom on the developmental stages of $G$. mellonella.

\begin{tabular}{|c|c|c|c|c|c|c|}
\hline $\begin{array}{l}\text { Conc. } \\
\text { (ppm) }\end{array}$ & $\begin{array}{c}\text { Larval } \\
\text { mortality }\end{array}$ & $\begin{array}{c}\text { Pupal } \\
\text { mortality }\end{array}$ & $\begin{array}{c}\text { Adult } \\
\text { mortality }\end{array}$ & $\begin{array}{c}\text { Total } \\
\text { mortality }\end{array}$ & $\begin{array}{l}\text { Corrected } \\
\text { mortality }\end{array}$ & $\begin{array}{l}\mathrm{LC}_{50} \\
(\mathrm{ppm})\end{array}$ \\
\hline 8000 & 40.00 & 33.33 & 0.00 & 60.00 & 60.00 & \multirow{7}{*}{3428.9} \\
\hline 4000 & 40.00 & 16.67 & 0.00 & 50.00 & 50.00 & \\
\hline 2000 & 40.00 & 16.67 & 0.00 & 50.00 & 50.00 & \\
\hline 1000 & 20.00 & 12.50 & 0.00 & 30.00 & 30.00 & \\
\hline 500 & 10.00 & 0.00 & 0.00 & 20.00 & 20.00 & \\
\hline 250 & 00.00 & 00.00 & 00.00 & 00.00 & 00.00 & \\
\hline Control & 00.00 & 00.00 & 00.00 & 00.00 & ---- & \\
\hline
\end{tabular}

Conc.: concentration level.

Table 2: Effects of the scorpion L. quinquestriatus venom on the growth and development of G. mellonella.

\begin{tabular}{|c|c|c|c|c|c|c|c|}
\hline \multirow[b]{2}{*}{$\begin{array}{l}\text { Conc. } \\
\text { (ppm) }\end{array}$} & \multicolumn{4}{|c|}{ Larval stage } & \multicolumn{3}{|c|}{ Pupal stage } \\
\hline & $\begin{array}{c}\text { Weight gain } \\
\text { (Mean mg } \\
\pm \text { SD) }\end{array}$ & $\begin{array}{c}\text { Growth rate } \\
\text { (Mean } \\
\pm \text { SD) }\end{array}$ & $\begin{array}{c}\text { Duration } \\
\text { (Mean days } \\
\pm \text { SD) }\end{array}$ & $\begin{array}{l}\text { Develop. } \\
\text { rate }\end{array}$ & $\begin{array}{c}\text { Pupation } \\
\text { (\%) }\end{array}$ & $\begin{array}{c}\text { Duration } \\
\text { (Mean days } \\
\pm \text { SD) }\end{array}$ & $\begin{array}{c}\text { Water loss } \\
(\%)\end{array}$ \\
\hline 8000 & $0.2208 \pm 0.01 \mathrm{~b}$ & $0.0025 \pm 0.007 \mathrm{~b}$ & $24.67 \pm 1.6 \mathrm{~d}$ & 4.05 & 50 & $7.92 \pm 2.1 \mathrm{~b}$ & 33.9 \\
\hline 4000 & $0.2231 \pm 0.01 \mathrm{a}$ & $0.0025 \pm 0.005 \mathrm{a}$ & $26.00 \pm 1.3 \mathrm{~d}$ & 3.85 & 60 & $7.99 \pm 2.2 \mathrm{a}$ & 34.22 \\
\hline 2000 & $0.2252 \pm 0.02 \mathrm{a}$ & $0.0024 \pm 0.005 \mathrm{a}$ & $27.00 \pm 1.4 \mathrm{~d}$ & 3.70 & 60 & $8.31 \pm 2.0 \mathrm{a}$ & 34.71 \\
\hline 1000 & $0.2261 \pm 0.01 \mathrm{a}$ & $0.0025 \pm 0.002 \mathrm{a}$ & $27.00 \pm 2.7 \mathrm{c}$ & 3.66 & 80 & $8.78 \pm 2.1 \mathrm{a}$ & 34.82 \\
\hline 500 & $0.2301 \pm 0.01 \mathrm{a}$ & $0.0025 \pm 0.004 \mathrm{a}$ & $27.33 \pm 2.0 \mathrm{~d}$ & 3.45 & 90 & $8.88 \pm 2.0 \mathrm{a}$ & 34.82 \\
\hline 250 & $0.2377 \pm 0.02 \mathrm{a}$ & $0.0025 \pm 0.005 \mathrm{a}$ & $29.00 \pm 1.3 \mathrm{~b}$ & 3.24 & 100 & $9.00 \pm 1.3 \mathrm{a}$ & 34.91 \\
\hline Control & $0.2387 \pm 0.03$ & $0.0029 \pm 0.005$ & $30.86 \pm 1.6$ & 3.24 & 100 & $9.00 \pm 1.2$ & 33.02 \\
\hline
\end{tabular}

Conc.: concentration level. Develop.: Developmental. Mean \pm SD followed with (a): insignificantly different $(\mathrm{P}>0.05)$. (b): significantly different $(\mathrm{P}<0.05)$, (c): highly significantly different $(\mathrm{P}<0.01)$. $(\mathrm{d})$ : very highly significantly different $(\mathrm{P}<0.001)$.

\section{DISCUSSION}

Insecticidal Activity of $\boldsymbol{L}$. quinquestriatus Venom Against G. mellonella:

Many researchers reported the effectiveness of venoms extracted from different 
scorpions against insect pests, since scorpion toxins exhibited high toxicity against some insects, such as leaf-eating moths, locusts, flies and beetles (Gurevitz, 2010). For example, the venom of the scorpion Mesobuthus tamulus was effective against the corn worm moth Heliothis virescens (Wudayagiri et al., 2001). The scorpion insectotoxin "AaIT" was tested on larvae of the diamondback moth Plutella xylostella. Within the first $24 \mathrm{~h}$, more than $60 \%$ of larvae were killed (Ji et al., 2002). The scorpion Tityus serrulatus venom exhibited toxicity against three insects from different orders, viz., Apis mellifera, Grillus assimilis, and Diatraea saccharalis (Manzoli-Palma et al., 2003). The venom of the scorpion Liocheles australasiae was toxic for some insects (Miyashita et al., 2007). The toxicity of venom solutions from some scorpion species was assessed against the mealworm Tenebrio molitor. The most potent toxicity was exhibited by the venom of $L$. quinquestriatus (Valk and Meijden, 2014).

Results of the present study were, to a great extent, in agreement with the previously reported results, since the treatment of newly moulted $3^{\text {rd }}$ instar larvae of the greater wax moth, Galleria mellonella, with six concentrations of the venom milked from the scorpion $L$. quinquestriatus exhibited toxicity against larvae. The pupae suffered a lethal action of the venom, in a dose-dependent course. In contrast, this venom failed to affect the adult survival. To explain the lethal effect of the L. quinquestriatus venom on larvae and pupae of $G$. mellonella, it might be due to certain chemical constituents of the venom, such as salts, small molecules, ions, neurotransmitters, peptides, and proteins (Moskowitz et al., 1998; Possani et al., 1999). This venom also contains enzymes, such as phospholipase, hyaluronidase, lipase, alkaline phosphotases, and proteolytic enzymes (Park et al., 2007). Also, L. quinquestriatus venom was found to contain different compounds similar to polypeptide neurotoxin, especially (Lqh7) and (lqh6) (Hamon et al., 2002). It contains, also, 5 toxic compounds of basic proteins with low molecular weight bound to disulphide bridges (Kopygan et al., 2006). However, different active toxins had been isolated from other scorpion species, such as "Pi1" from Pandinus imperator (Rogowski et al., 1996), noxiustoxin, and margatoxin from Centruroides limpidus (Kharrat et al., 1996) and maurotoxin from Scorpio mauruspalmatus (Carlier et al., 2000).

In general, the larval deaths of G. mellonella by the tested arthropod products, in the current work, may be attributed to the failure of larvae to moult owing to the inhibition of chitin formation (Abdel Rahman et al., 2007; Adel, 2012) or to the inability to shed their exocuticle during ecdysis (Linton et al., 1997). Also, the larval deaths might be due to the antifeedant activities of the present venoms and secretion causing continuous starvation of larvae (Ghoneim et al., 2000). The pupal deaths in G. mellonella could be directly or indirectly relate to activities of the tested venom against some vital processes, such as suffocation, bleeding and desiccation owing to imperfect exuviation, failure of vital homeostatic mechanisms, etc. (Smagghe and Degheele, 1994). This suggestion can easily be substantiated since the tested $L$. quinquestriatus venom exerted a general desiccating action on pupae after treatment of $3^{\text {rd }}$ instar larvae of G. mellonella, in the present study.

With regard to the $\mathrm{LC}_{50}$ of $L$. quinquestriatus venom against $G$. mellonella, in the present study, it was calculated in $3428.9 \mathrm{ppm}$. Thus, the toxicity of the $L$. quinquestriatus venom was weak in comparison with other scorpion venoms, such as scorpion Odontobuthus odonturus against the aphid Rhopalosiphum erysimi, since Tahir et al. (2015) calculated it as $0.44 \mu \mathrm{l}$. However, LC 50 values depend on several factors, such as susceptibility of the insect and its treated stage or instar, lethal potency of the tested compound or venom and its concentration levels, method and time of treatment, as well as the experimental conditions (Ghoneim et al., 2017). 


\section{Disrupted Growth and Development of G. mellonella by L. quinquestriatus Venom:}

On the basis of the available literature, different products and compounds of animal origin showed disruptive effects on the development of various insect pests. In the present investigation, the somatic weight gain of $G$. mellonella larvae was reduced proportionally to the concentration level of $L$. quinquestriatus venom. Also, the larval growth rate is increasingly regressed by the ascending concentration.

The inhibited growth of G. mellonella, in the current study, might be a result of the blocked release of certain peptides, causing an alteration in the ecdysteroid and juvenoid titers (Barnby and Klocke, 1990), since the scorpion L. quinquestriatus venom contains different biologically active compounds similar to polypeptide neurotoxin (Tan et al., 2006; Ortiz and Possani, 2015). Two types of venoms were identified in $L$. quinquestriatus venom (Lqh7) and (lqh6) (Hamon et al., 2002). Some of these constituents might affect the tissues and cells undergoing mitosis (Nasiruddin and Mordue, 1994).

The larval duration and pupal duration of G. mellonella, in the current study, had been remarkably shortened, in a venom dose-dependent manner. The present shortened durations of larvae and pupae might be due to their avoiding the adverse actions of the tested venom, as a xenobiotic agent. Also, the L. quinquestriatus venom might prevent the formation of the nuclear receptor of the cells, causing a disturbance in the developmental durations (Riddiford and Truman, 1993).

In the present study, the pupation rate of treated $G$. mellonella larvae was regressed after larval treatment with the majority of concentration levels of $L$. quinquestriatus venom. In other words, scorpion venom hindered the pupation process in a dose-dependent course. For interpretation of the regression of pupation rate, the tested venom might exert a suppressive action on the chitin synthesis to prevent the normal deposition of the new cuticle during pupation (Retnakaran et al., 1985). On the other hand, the tested venom failed to affect the metamorphosis program of G. mellonella, since no larval-pupal or malformed pupae had been produced. Unfortunately, we have no conceivable explication of this failure!!

\section{Conclusion:}

Depending on the results of the present study on G. mellonella, L. quinquestriatus venom exhibited high toxicity on larvae and pupae, at the majority of concentrations. Also, it significantly reduced the somatic weight gain, larval growth rate, and blocked the pupation as well as affected the larval and pupal durations. Therefore, this venom should be taken into account among other efficient components of the integrated management program against G. mellonella. However, novel delivery systems should be explored in order for the scorpion toxins can find their way into commercial applications in foreseeable future.

\section{REFERENCES}

Abbasipour, H.; Mahmoudvand, M.; Deylami, A. and Hosseinpour, M.H. (2009): Fumigant toxicity of essential oils of Rosemarinus officinalis L. and Eucalyptus camodulensis Deh. against some stored products pests, Proceeding of the $6^{\text {th }}$ AsiaPasific Congress of Entomology, Entomology in Health, Agriculture and Environment, Beijing, China.

Abbott, W.S. (1925): A method of computing the effectiveness of insecticide. Journal of Economic Entomology, 18(2): 265-267.

Abdel Rahman, S.M.; Hegazy, E.M. and Elweg, A.E. (2007): Direct and latent effect of two chitin synthesis inhibitors on Spodoptera littoralis larvae (Boisd.). American 
Eurasian Journal of Agricultural and Environmental Sciences, 2(4): 454-464.

Adel, M.M. (2012): Lufenuron impair the chitin synthesis and development of Spodoptera littoralis Bosid. (Lepidoptera: Noctuidae). Journal of Applied Science Research, 8(5): 27-66.

Ahmed, S.M.; Naguib, S.M.; Rashad, A.M.; Abdallah, M.Z. and El-Deeb, Y.A. (1993): Comparison between some body contents in different physiological cases of the $4^{\text {th }}$ instar larvae of Pectinophora gossypiella (Saund.), (Lepidoptera: Gelechiidae). Journal of Agricultural Research (Al-Azhar University), 17: 249-258.

Akyol, E.; Yeninar, H.; Şahinler, N. and Ceylan, D.A. (2009): The using of carbon dioxide $\left(\mathrm{CO}_{2}\right)$ on controlling of the greater wax moth's Galleria mellonella L. (Lepidoptera: Pyralidae) damages. Uludag Bee Journal, 9(1): 26-31. (In Turkish with extended English abstract).

Altstein, M. (2004): Novel insect control agents based on neuropeptide antagonists: the PK/PBAN family as a case study. Journal of Molecular Neuroscience, 22 (1-2): $147-157$.

Altstein, M.; Ben-Aziz, O.; Schefler, I.; Zeltser, I. and Gilon, C. (2000): Advances in the application of neuropeptides in insect control. Crop Protection, 19 (8-10): 547555.

Armendariz, I.; Downes, M.J.; Griffin, C.T. (2002): Effect of timber condition on parasitization of pine weevil (Hylobius abietis L.) larvae by entomopathogenic nematodes under laboratory conditions. Biocontrol Science and Technology, 12: 225-233.

Awasthi, P. and Sharma, P. (2012): Docking Study of synthesized juvenile hormone analogues as an Insect Growth Regulators. 2012 UK Sim $14^{\text {th }}$ International Conference on Computer Modelling and Simulation. Cambridge, Cambridgeshire United Kingdom, March 28-March 30

Awasthi, P. and Sharma, P. (2013): Designing and binding mode prediction of juvenile hormone analogues as potential inhibitor for Galleria mellonella. Journal of Computer Science \& Systems Biology, 6(3): 106-111.

Badry, A.; Younes, M.; Sarhan, M. M. and Saleh, M. (2018): On the scorpion fauna of Egypt, with an identification key (Arachnida: Scorpiones). Zoology in the Middle East, 64(1): 75-87.

Barnby, M.A. and Klocke, J.A. (1990): Effects of azadirachtin on levels of ecdysteroids and prothoracicotropic hormone-like activity in Heliothis virescens (Fabr.) larvae. Journal of Insect Physiology, 36: 125-131.

Basedow, T.; Shafie, H.; Abo-El-Saad, M. and Al Ajlan, A. (2012): Evaluation of Bacillus thuringiensis aizawi and neem for controlling the larvae of the greater wax moth, Galleria mellonela (Lepidopthera: Pyralidae). International Journal of Agricultural Biology, 14: 60-63.

Bhatnagar, A. and Bareth, S.S. (2004): Development of low cost, high quality diet for greater wax moth, Galleria mellonella (Linnaeus). Indian Journal of Entomology, 66(3): 251-255.

Calderone, N. (2000): IPM-wax moths, mice, wasps and robber bees. Bee Culture Magazine, 128(15): 34-56.

Cao, Z.; Yu, Y. and Li, W. (2013): The genome of Mesobuthus martensii reveals a unique adaptation model of arthropods. Nature Communications, 4: 2602.

Carlier, E.; Avdonin, V.; Geib, S.; Fajloun, Z.; Kharrat, R.; Rochat, H.; Sabatier, J.-M.; Hoshi, T. and De Waard, M. (2000): Effect of maurotoxin, a four disulfidebridged toxin from the chactide scorpion, Scorpio maurus, on shaker $\mathrm{K}^{+}$channels. Journal of Peptide Research, 55: 419-427. 
Carpenter, J.; Bloem, S. and Marec, F. (2005): Inherited sterility in insects. In: "Sterile Insect Technique"(Dyck, V.A.; Hendrichs, J.; Robinson, A.S., eds.). pp: 115-146.

Chandel, Y.S.; Sharma, S. and Verma, K.S. (2003): Comparative biology of the greater wax moth, Galleria mellonella L. and lesser wax moth, Achoria grisella. Forest Pest Management and Economic Zoology, 11: 69-74.

Christen, J.M.; Campbell, J.F.; Zurek, L.; Shapiro-Ilan, D.I.; Lewis, E.E.; Ramaswamy, S.B. (2008): Role of symbiotic and non-symbiotic bacteria in carbon dioxide production from hosts infected with Steinernema riobrave. Journal of Invertebrate Pathology, 99(1): 35-42.

Dahlman, D.L.; Rana, R.L.; Schepers, E.J.; Schepers, T.; Diluna, F.A. and Webb, B.A. (2003): A teratocyte gene from a parasitic wasp that is associated with inhibition of insect growth and development inhibits host protein synthesis. Insect Molecular Biology, 12: 527-534.

Dindo, M.L.; Verdinelli, M.; Baronio, P.; Serra, G.E. (2001): Laboratory and field performance of in vitro and in vivo reared Exorista larvarum (L.), a natural enemy of cork oak defoliators. In: "Integrated protection in oak forests" (Villemant, C. and Sousa, E., eds.). Proceedings of the IUBC-WPRS working group at Oeiras Lisbonee, Portugal, $01^{\text {st }}-04^{\text {th }}$ Oct., 2001. Bulletin Oilb-Srop, 25: 147-150.

Durmuş, Y. and Büyükgüzel, K. (2008): Biological and immune response of Galleria mellonella (Lepidoptera: Pyralidae) to sodium tetraborate. Journal of Economic Entomology, 101(3):777-783.

Ebadi, R.; Jafari, R.; Majd, F.; Tahmasbi, G. and Zolphagharieh, H. (2001): Effect of gamma-ray male sterilization on the integrated control management of greater wax moth, Galleria mellonella L. (Lep., Pyralidae). JWSS - Isfahan University of Technology; 5 (3):191-199.

Elbehery, H.; Abd El-Wahab, T.E. and Dimetry, N.Z. (2016): Management of the greater wax moth Galleria mellonella with Neemazal-T/S, in the laboratory and under semi-field conditions. Journal of Apiculture Science, 60(2): 69-76.

El-Hennawy, H.K. (1987): A simplified key to Egyptian scorpion species (Arachnida: Scorpionida). Serket, 1: 15-17.

El-Kholy, E.M.S. and Mikhaiel, A.A. (2008): Scanning electron microscopy on the male antennae of the greater wax moth, Galleria mellonella (L.), treated with gamma radiation. Isotope and Radiation Researchs, 40(3): 603-613.

Ellis, J.D.; Graham, J.R. and Mortensen, A. (2013): Standard methods for wax moth research. Journal of Apiculture Research, 52: 1-17.

Er, A.; Taşkıran, D. and Sak, O. (2017): Azadirachtin-induced effects on various life history traits and cellular immune reactions of Galleria mellonella (Lepidoptera: Pyralidae). Archives of Biological Sciences, 69(2): 335-344. https://doi.org/ 10.2298/ABS160421108E.

Fabiano, G.; Pezzolla, A.; Filograna, M.A. and Ferrarese, F. (2008): Traumatic shockphysiopathologic aspects. Giornale di chirurgia, 29: 51-57 (In Italy, with English summary)

Finney, D.J. (1971): Probit analysis. $3^{\text {rd }}$ ed. Cambridge, England: Cambridge University Press, 318 pp.

Frost, L.M.; Butler, D.R.; O'Dell, B. and Fet, V. (2001): A coumarin as a fluorescent compound in scorpion cuticle. In: "Scorpions 2001: in memoriam, Gary, A." (Fet, V. and Selden, P.A., eds.). Polis: British Arachnological Society, pp: 365-368.

Froy, O.; Zilberberg, N.; Chejanovsky, N.; Anglister, J.; Loret, E.P.; Shaanan, B.; Gordon, D. and Gurevitz, M. (2000): Scorpion neurotoxins: structure/function relationships and application in agriculture. Pest Management Science, 56: 472- 
474. DOI: 10.1002/ (SICI)1526-4998(200005)56:5<472: AID-PS148>3.3.CO;2-6

George, J.; Devi, G. and Bhattacharyya, B. (2019): Survival and infectivity of entomopathogenic nematode Oscheius rugaoensis in different formulations against wax moth, Galleria mellonella. Journal of Entomology and Zoology Studies, 7(3): 241-244.

Ghoneim, K.S.; Mohamed, H.A. and Bream, A.S. (2000): Efficacy of the neem seed extract, Neemazal, on growth and development of the Egyptian cotton leafworrn, Spodoptera littoralis Boisd. (Lepidoptera: Nocutidae). Journal of Egyptian German Society of Zoology, 33: 161-179.

Ghoneim, K.; Hassan, H.A.; Tanani, M.A. and Bakr, N.A. (2017): Deteriorated larval haemogram in the pink bollworm, Pectinophora gossypiella (Saunders) (Lepidoptera: Gelechiidae) by the chitin synthesis inhibitors, Novaluron and Diofenolan. International Journal of Modern Research and Reviews, 5(2): 14871504.

Gurevitz, M. (2010): A deadly scorpion provides a safe pesticide. Science news, Tel Aviv University, January 19, 2010 http://www.sciencedaily.com

Hamon, A.; Gilles, N.; Sautiere, P.; Kopeyan, C.; Ulens, C.; Tytgat, J.; Lancelin, J. and Gordon, D. (2002): Characterization of Scorpion a-like toxin group using tow new toxins from the Scorpion, Leiurus quinquestriatus hebraeus. European Journal of Biochemistry, 269(16): 3920-3933.

Harrison, R.L. and Bonning, B.C. (2000): Use of scorpion neurotoxins to improve the insecticidal activity of Rachiplusia ou multicapsid nucleopolyhedrovirus. Biological Control, 17(2): 191-201.

Hussaini, S.S. (2003): Progress of research work on entomopathogenic nematodes in India. In: "Current status of research entomopathogenic Nematodes in India" (Hussaini, S.S.; Rabindra, R.J. and Nagesh, M., eds.). pp. 27-69. PdbC, publication, Bangalore, India.

İzzetoglu, S. and Karacali, S. (2003): The effects of 20-hydroxyecdysone on haemocytes of Galleria mellonella (Lepidoptera) in vitro conditions. Gazi Univer. Journal of Science (Turkey), 16(2): 233-238.

James, R.R. (2011): Potential of ozone as a fumigant to control pests in honey bee (Hymenoptera: Apidae) hives. Journal of Economic Entomology, 104: 353-359.

Ji, Y.H.; Wang, W.X.; Wang, Q. and Huang, Y.P. (2002): The binding of BmK abT, a unique neurotoxin, to mammal brain and insect $\mathrm{Na}(+)$ channels using biosensor. European Journal of Pharmacology, 454: 25-30.

Joseph, B. and George, J. (2012): Scorpion Toxins and its Applications. International Journal of Toxicological and Pharmacological Research, 4(3): 57-61.

Khalil, M.S.; Younes, M.W.F.; Sakr, H. (1993): The extending effect of gamma radiation on the adult Galleria mellonella L. (Lepidoptera: Galleridae). Proceedings of "First Arab conference on the peaceful uses of atomic energy", 2-6 Feb 1992, Tripoli, Libya (Al Kofahi, M., ed.): 796 pages.

Kharrat, R.; Mabrouk, K.; Crest, M.; Darbon, H.; Oughideni, R.; Martin-Eauclaire, M.F.; Jacquet, G.; El Ayeb, M.; Van Rietschoten, J., Rochat, H. and Sabatier, J.M. (1996): Chemical synthesis and characterization of maurotoxin, a short scorpion toxin with four disulfide bridges that acts on $\mathrm{K}^{+}$channels. European Journal of Biochemistry, 242: 491-498.

Kopegan, C.; Martinez, G. and Rochat, H. (2006): Primary structure of toxin IV of Leiurus quinquestriatus. INSERM. U. CNRS.UA, 181(2): 553-559.

Kwadha, C.A.; Ong'amo, G.O.; Ndegwa, P.N.; Raina, S.K. and Fombong, A.T. (2017): The biology and control of the greater wax moth, Galleria mellonella. Insects, 8: 
61.

Leng, P.; Zhang, Z.; Pan, G. and Zhao, M. (2011): Applications and development trends in biopesticides. African Journal of Biotechnology, 10: 19864-19873.

Linton, Y.M.; Nisbet, A.J. and Mordue (Luntz), A.J. (1997): The effect of azadirachtin on the testes of the desert locust Schistocerca gregaria (Forskal). Journal of Insect Physiology, 43: 1077-1084.

Ma, J. and Shi, Y.B. (2014): The Mesobuthus martensii genome reveals the molecular diversity of scorpion toxins. Cell \& Bioscience, 4:1. 2pp. doi:10.1186/2045-37014-1

Mahmoudvand, M.; Habib Abbasipour, H.; Mohammad Hossein Hosseinpour, M.H.; Fahimeh Rastegar, F. and Basij, M. (2011): Using some plant essential oils as natural fumigants against adults of Callosobruchus maculatus (F.) (Coleoptera: Bruchidae). Munis Entomology \& Zoology, 6(1):150-154.

Manzoli-Palma, M.F.; Gobbi, N. and Palma, M.S. (2003): Insects as biological models to assay spider and scorpion venom toxicity. Journal of Venomous Animals and Toxins including Tropical Diseases, 9(2): 174-185.

Metwally, H.M.S.; Hafez, G.A.; Hussein, M.A.; Salem, H.A. and Saleh, M.M.E. (2012): Low cost artificial diet for rearing the greater wax moth, Galleria mellonella L. (Lepidoptera: Pyralidae) as a host for entomopathogenic nematodes. Egyptian Journal of Biological Pest Control, 22(1): 15-22.

Miyashita, M.; Otsuki, J.; Hanai, Y.; Nakagawa, Y. and Miyagawa, H. (2007): Characterization of peptide components in the venom of the scorpion Liocheles australasiae (Hemiscorpiidae). Toxicon, 50: 428-437.

Mohamed, H.F.; El-Naggar, S.E.M.; Elbarky, N.M.; Ibrahim, A.A. and Salama, M.S. (2014): The impact of each of the essential oils of marjoram and lemon grass in conjunction with Gamma irradiation against the greater wax moth, Galleria mellonella. IOSR Journal of Pharmacy and Biological Sciences, 9(5): 92-106.

Moroney, M.J. (1956): Facts from figures ( ${ }^{\text {rd }}$ ed.). Penguin Books Ltd., Harmondsworth. Middle Sex.

Moskowitz, H.; Herrmann, R.; Jones, A.D. and Hammock, B.D. (1998): A depressant insect- selective toxin analog form the venom of the scorpion, Leiurus quinquestriatus hebraeus purification and structure/function characterization. European Journal of Biochemistry, 254: 44-49.

Nakasu, E.Y.T.; Williamson, S.M.; Edwards, M.G.; Fitches, E.C.; Gatehouse, J.A. and Wright, G.A. (2014): Novel biopesticide based on a spider venom peptide shows no adverse effects on honeybees. Proceedings of Biological Science, 281: pii: 20140619 10.1098/rspb.2014.0619.

Nasiruddin, M. and Mordue (Luntz), A.J. (1994): The protection of barley seedlings from attack by Schistocerca gregaria using azadirachtin and related analogues. Entomologia Experimentalis et Applicata, 70: 247-252.

Nicholson, G.M. (2006): Spider venom peptides. In: "The Handbook of Biologically Active Peptides"(Kastin, A.J., ed.). Elsevier, San Diego, CA, pp: 389-399.

Nitin, K.; Kumar, K.D.; Kumar, M.V. and Sanjay, P. (2012): Effect of economical modification in artificial diet of greater wax moth Galleria mellonella (Lepidoptera: Pyralidae). Indian Journal of Entomology, 74(4): 369-374.

Olivera, B.M. (2002): Conus venom peptides: reflections from the biology of clades and species. Annual Review of Ecological System, 33: 25-47.

Ortiz, E. and Possani, L.D. (2015): The unfulfilled promises of scorpion insectotoxins. Journal of Venomous Animals and Toxins including Tropical Diseases, 21:16, 7pp. Doi: 10.1186/s40409-015-0019-6. 
Owayss, A.A. and Abd-Elgayed, A.A. (2007): Potential efficacy of certain plant volatile oils and chemicals against greater wax moth Galleria mellonella L. (Lepidoptera: Pyralidae). Bulletin of Entomological Society of Egypt, (Economic Series), 33: 6775.

Pamita, A. and Priyanka, S. (2013): Designing and binding mode prediction of juvenile hormone analogues as potential inhibitor for Galleria mellonella. Journal of Computer Science and System Biology, 6: 106-111.

Park, J.; Cho, S.Y. and Choi, S.J. (2007): Purification and characterization of hepatic lipase from Todarodes pacificus. BMB reports, pp: 254-258.

Possani, L.D.; Becerril, B.; Delepierre, M. and Tytgat, J. (1999): Scorpion toxins specific for Na+ -channels. European Journal of Biochemistry, 264(2): 287-300.

Possani, L.D.; Merino, E.; Corona, M.; Bolivar, F. and Becerril, B. (2000): Peptides and genes coding for scorpion toxins that affect ion-channels. Biochimie, 82(9): 8618. http://dx.doi.org/10.1016/ S0300-9084(00)01167-6

Rajendran, S. and Sriranjini, V. (2008): Plant products as fumigants for stored-product insect control. Journal of Stored Products Research, 44: 126-135.

Ramos-Rodríguez, O.; Campbell, J.F.; Lewis, E.E.; Shapiro-Ilan, D.I. and Ramaswamy, S.B. (2007): Dynamics of carbon dioxide release from insects infected with entomopathogenic nematodes. Journal of Invertebrate Pathology, 94(1): 64-69.

Retnakaran, A.; Granett, J. and Ennis, T. (1985): Insect growth regulators. In: "Comprehensive Insect Physiology, Biochemistry and Pharmacology" (Kerkut, G.A., Gilbert, L.I., eds.). vol.12. Pergamon, Oxford, pp.: 529-601.

Riddiford, L.M. and Truman, J.W. (1993): Hormone receptors and the regulation of insect metamorphosis. American Zoology, 33: 340- 347.

Rogowski, R.S.; Collins, J.H.; O'Neill, T.J.; Gustafson, T.A.; Werkman, T.R.; Rogawski, M.A.; Tenenholz, T.C.; Weber, D.J. and Blaustein, M.P. (1996) Three new toxins from the scorpion Pandinus imperator selectively block certain voltage-gated $\mathrm{K}^{+}$ channels. Molecular Pharmacology, 50: 1167-1177.

Sak, O. and Uckan, F. (2009): Effets of cypermethrin on the pupation and mortality of Galleria mellonella L. (Lepidoptera: Pyralidae). Uludag Bee Journal, 9(3): 88-96.

Saleh, M.; Younes, M.; Badry, A. and Sarhan, M. (2017): Zoogeographical analysis of the Egyptian scorpion fauna. Al Azhar Bulletin of Science, 28(1): 1- 14.

Sarhan, M.; Maged, M.F.; Alaa, M.H.; Hamdy, A.M. and Ahmed B.S. (2012): Variation of protein profile among consecutive stings of the scorpion Parabuthus leiosoma (Family: Buthidae) from Egypt, supports the venom-metering hypothesis in scorpions. Al Azhar Bulletin of Science, 23(1): 61-71.

Savela, M. (2009): Markku Savela's Lepidoptera and some other life forms Galleria. Version of 2009-APR-07. Retrieved 2010-APR-11.

Smagghe, G. and Degheele, D. (1994): Action of a novel nonsteroidal ecdysteroid mimic, tebufenozide (RH-5992), on insects of different orders. Pesticide Science, 42: 8592.

Tahir, H.M.; Zafar, K.; Mishal, R.; Naseem, S.; Butt, A.; Yaqoob, R.; Ahsan, M.M. and Arshad, M. (2015): Potential use of venom of Odontobuthus odonturus (Arachnida: Buthidae) as bio-pesticide against Rhopalosiphum erysimi (Homoptera: Aphididae). Pakistan Journal of Zoology, 47(1): 37-40.

Tan, P.T.J.; Veeramani, A.; Srinivasan, K.N.; Ranganathan, S. and Brusic, V. (2006): Scorpions: a database for structure-function analysis of scorpion toxins. Toxicon, 47: 356-363.

Taniai, K.; Inceoglu, A.B. and Hammock, B.D. (2002): Expression efficiency of a scorpion neurotoxin, AaHIT, using baculovirus in insect cells. Applied 
Entomology and Zoology, 37(2): 225-232.

Tedford, H.W.; Sollod, B.L.; Maggio, F. and King, G.F. (2004): Australian funnel-web spiders: master insecticide chemists. Toxicon, 43: 601-618.

Unsal, S.; Ozparlak, H. and Aktumsek, A. (2004): Effects of diflubenzuron on the integument of fifth instar Galleria mellonella larvae. Phytoparasitica, 32 (1): 4351.

Vachon, M. (1966): Liste des scorpions connusen Égypte, Arabie, Israël, Liban, Syrie, Jordanie, Turquie, Irak, Iran. Toxicon, 4(3): 209-218.

Valk, T. and Meijden, A. (2014): Toxicity of scorpion venom in chick embryo and mealworm assay depending on the use of the soluble fraction versus the whole venom. Toxicon, 88: 38-43.

Waldbauer, G.P. (1968): The consumption and utilization of food by insects. Advances in Insect Physiology, 5: 229-288.

Whetstone, P.A. and Hammock, B.D. (2007): Delivery methods for peptide and protein toxins in insect control. Toxicon, 49: 576-596.

Willems, J.; Noppe, W.; Moerman, L.; Van der, WJ. and Verdonck, F. (2002): Cationic peptides from scorpion venom can stimulate and inhibit polymorphonuclear granulocytes. Toxicon, 40: 1679.

Williams, S.S.C. (1968): Scorpion preservation for taxonomic and morphological studies. The Wasmann Journal of Biology, 26(1): 133-136.

Windley, M.J.; Herzig, V.; Dziemborowicz, S.A.; Hardy, M.C.; King, G. F. and Nicholson, G.M. (2012): Spider-venom peptides as bioinsecticides. Toxins (Basel); 4(3):191-227. doi: 10.3390/toxins 4030191.

Wudayagiri, R.; Inceoglu, B.; Herrmann, R.; Derbel, M.; Choudary, V.P. and Hammock, D.B. (2001): Isolation and characterization of a novel lepidopteran-selective toxin from the venom of South Indian red scorpion, Mesobuthus tumulus. BMC Biochemistry, 2:16. 